\title{
Strengths use, deficit correction, thriving and performance of academics at universities of technology
}

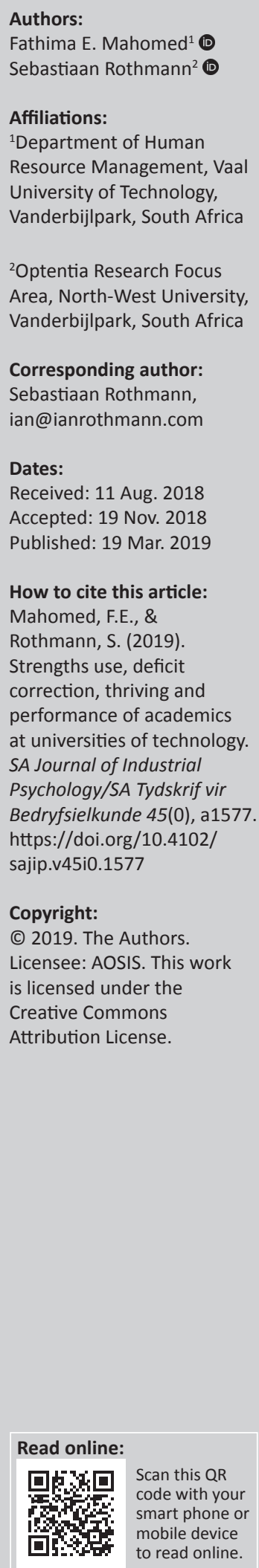

Orientation: Research regarding strengths use, deficit correction and thriving of academics in higher education institutions is necessary, given the possible effects thereof on their task and contextual performance.

Research purpose: This study aimed to investigate the relationships among strengths use and deficit correction, thriving at work and performance of academics. Furthermore, it sought to investigate whether performance-related pay moderates the effects of thriving on performance.

Motivation for the study: No studies were found regarding the relationships among a balanced strengths- and deficit-based approach, thriving at work, and performance in the context of South African higher education.

Research approach/design and method: A cross-sectional survey design was used, with a convenience sample of 276 academic employees from three universities of technology in South Africa. The participants completed the Strengths Use and Deficit Correction Scale, the Thriving at Work Scale, a scale that measured perceptions of performance-related pay and measures of task and contextual performance.

Main findings: The results showed that perceived organisational support for strengths use, as well as individual strengths use and deficit correction, predicted thriving at work. Thriving predicted task and contextual performance. A significant interaction was found between thriving and perceptions of performance-related pay. The most robust relation between thriving and performance existed when performance-related pay was perceived to be good.

Practical/managerial implications: Higher education institutions must invest resources to enable academics to thrive at work via the balanced strength- and deficit-based approach. This approach should be seen as a core development tool for academics to increase employees' thriving at work.

Contribution/value-add: This study contributes to scientific knowledge regarding strengths use and deficit correction, thriving and performance of academics in higher education institutions. It also resulted in new knowledge regarding the interaction effects of performancerelated pay and thriving on task performance of academics.

\section{Introduction}

Individuals have an inherent drive for self-improvement and growth (Ryan \& Deci, 2017). This drive can expose people to situational demands that might overwhelm them so that they either struggle and give in or survive. Alternatively, they might thrive (Brown, Arnold, Fletcher, \& Standage, 2017). In a quest to understand how individuals achieve fulfilment, it is necessary to study why some people thrive in certain situations, whereas others merely survive or give in. Seligman and Csikszentmihalyi (2000, p. 13) predicted that in the 21st century, 'a psychology of positive human functioning will arise that achieves a scientific understanding and effective interventions to build thriving in individuals, families, and communities'.

Individual strengths have been associated with positive human functioning (Seligman 2011) and positive affect (Littman-Ovadia, Lavy, \& Boiman-Meshita, 2017). Recent studies (e.g. LittmanOvadia \& Lavy, 2016; Littman-Ovadia \& Steger, 2010) have also linked strengths with positive experiences at the workplace. However, measuring the extent to which individuals use their strengths, thus fulfilling their potential at work, is essential, beyond the mere identification of these strengths. Studies suggest that the mechanisms underlying the effects of strengths use are 
different from those underlying the effects of strengths endorsement (Lavy \& Littman-Ovadia, 2016; Littman-Ovadia \& Lavy, 2016).

A comprehensive understanding of human strengths and deficits, as well as perceived organisational support for strengths use (POSSU) and deficit correction (POSDC), is needed to make informed decisions on how to support employees to achieve their full potential. The deficit-based approach (DBA) is valuable for purposes of individual and organisational development. However, the strengths-based approach (SBA) focuses on the strengths and potential of individuals and organisations (Linley, Joseph, Harrington, \& Wood, 2006; Seligman \& Csikszentmihalyi, 2000). The SBA makes it possible to study and develop the talents and virtues of people (Buckingham \& Clifton, 2001). Researchers (Bouskila-Yam \& Kluger, 2011; Longenecker, 2010; Sienstra, 2010) suggest that the SBA, performance, engagement and well-being are positively related (Harzer \& Ruch, 2013; Keenan \& Mostert, 2013; Mphahlele, Els, De Beer, \& Mostert, 2018). However, increased performance can also result from DBA (Abdullah, Ahsan, \& Alam, 2009). Therefore, focusing on both strengths use and deficit correction may be beneficial for an organisation (Els, Mostert, \& Van Woerkom, 2018).

According to the organisational support theory (Eisenberger, Fasolo, \& Davis-LaMastro, 1990; Rhoades \& Eisenberger, 2002), employees form a general belief concerning the extent to which the organisation appreciates their contribution and is concerned about their well-being. Such positive organisational support (POS) is associated with greater psychological well-being, more positive orientation towards the organisation and behavioural outcomes helpful to the organisation (Allen, Shore, \& Griffeth, 2003; Rhoades \& Eisenberger, 2002). According to Van Woerkom et al. (2016), individuals depend on organisations to support them to develop and use their strengths and improve their deficits. Furthermore, Van Woerkom et al. (2016) compared the effects of a focus on strengths use and deficit correction. They questioned which of these approaches (or combination thereof) lead to the most favourable outcomes. The results of other studies (e.g. Botha \& Mostert, 2014; Mostert, Theron, \& De Beer, 2017; Mphahlele et al., 2018) showed that POS for both strengths use and deficit correction predicted work engagement and learning.

No studies were found regarding the relationships among a balanced strengths-and-deficit-based approach, thriving at work and performance in South African higher education. Drawing on the work conducted by Van Woerkom et al. (2016) and others, an investigation is necessary to determine the extent to which POS for strengths use and for deficit correction, as well as strengths use behaviour (SUB) and deficit correction behaviour (DCB), contribute to thriving at work and better performance, among academics. Furthermore, performance-related pay might moderate the effect of thriving on performance. More specifically, thriving might be stronger related to performance when performancerelated pay is perceived. The thriving-performance relation might be weaker when performance-related pay is regarded as poor. However, it is not clear whether performance-related pay will interact with thriving at work to affect the performance of academics.

\section{Literature review Thriving}

The concept of thriving at work has recently received a great deal of attention in positive organisational scholarship (Paterson, Luthans, \& Jeung, 2014; Spreitzer \& Porath, 2012). Thriving is characterised by the joint experience of learning and vitality (Spreitzer \& Sutcliffe, 2007; Spreitzer et al., 2005) and is considered distinct from subjective well-being and work engagement (Carmeli \& Spreitzer, 2009; Spreitzer et al., 2005; Spreitzer, Lam, \& Fritz, 2010). Subjective well-being captures the hedonic dimension of well-being, while thriving incorporates both hedonic and eudemonic dimensions. Thriving at work and work engagement (Bakker, Schaufeli, Leiter, \& Taris, 2008) overlap to a degree. In both models, available energy (termed 'vitality' or 'vigour') is the main component. However, work engagement does not require experiences of learning, as it is more concentrated around experiences of dedication and absorption (Spreitzer et al., 2010).

\section{Perceived organisational support for strengths use and deficit correction}

Organisational climate is an important contextual element identified by various researchers as leading to different behavioural outcomes (Yuan \& Woodman, 2010). Van Woerkom et al. (2016) derived the concepts of POS for strengths use and deficit correction on the foundation of the organisational support theory. Perceived organisational support for strengths use is a strategic sign of employee perceptions of how their organisation treats them (Zagenczyk et al., 2010) and is defined as 'employees' general belief that their organisation values their contribution and cares about their well-being' (Rhoades \& Eisenberger, 2002, p. 699). If employees perceive that their organisation supports and looks after their well-being, it might increase their interest in their work (Rhoades \& Eisenberger, 2002, p. 699) and enhance the sense of liveliness in the workplace, promoting the learning of new things to reciprocate and contribute to the success of organisations.

Thriving at work is a psychological state (Spreitzer, Sutcliffe, Dutton, Sonenschein, \& Grant, 2005). When employees experience thriving at work, they feel the drive to work and learn, which increases their short-term functioning, their longer-term development and, hence, their performance (Porath, Spreitzer, Gibson \& Granett, 2012). According to Zagenczyk et al. (2010), perceived organisational support is a strategic sign of employee perception of how their organisation treats them. Wiesenfeld, Raghuram and Garud (2001) argue that support from organisations increases the workers' feelings of being respected and appreciated, which again enhance motivation for learning new things and give a 
sense of feeling energised. Thus, a supportive environment should improve thriving at work. Perceived organisational support for strengths use is defined as the extent to which employees believe and observe that their organisations encourage the use and application of their strengths in the workplace (Van Woerkom et al., 2016). As mentioned previously, evidence suggests that POS for strengths use is a significant predictor of work-related aspects such as engagement (Stander \& Mostert, 2013) and job performance (Van Woerkom \& Meyers, 2015).

The DBA has served persistently in addressing critical areas of shortage in individuals and organisations to attain goals and facilitate growth. It is the training and development functions of organisations that have long been sanctioned to design and convene intercessions to resolve areas of development identified in the organisation as a means of ensuring higher levels of performance and growth (Clifton \& Harter, 2003; Linley \& Harrington, 2006a, 2006b). However, these are also linked to negativity, including the possibility of draining the energy levels of employees and leading to negative feelings resembling frustration and anxiety (Page \& Vella-Broderick, 2008). Furthermore, focusing only on weaknesses might prevent employees from adding value and hinder their performance and their sense of well-being (Roberts et al., 2005).

As far as deficit correction is concerned, employees also rely on support from organisations to enhance and develop correction of their deficits. Positive organisational support for deficit correction is defined as the extent to which individuals believe that organisations that employ them, support them to improve their deficits or weaknesses in the workplace (Van Woerkom et al., 2016). Another positive organisational outcome linked to deficit improvement is organisational commitment (Bartlett, 2001).

\section{Employees' proactive behaviour towards strengths use and deficit correction}

The concept of individual strengths refers to specific individual characteristics, abilities and traits that, when actualised, energise a person and permit performance at his or her personal best (Linley \& Harrington, 2006a, 2006b). Although strengths are trait-like (Peterson \& Seligman, 2004), the way strengths are applied is dependent on context, values, interests and other strengths (Biswas-Diener, Kashdan, \& Minhas, 2011). Research has indicated that when employees know, develop and utilise their strengths, it leads to positive psychological and behavioural outcomes (Biswas-Diener et al., 2011). Some studies focused on the relationship between strengths use and well-being (Govindji \& Linley, 2007; Wood, Linley, Maltby, Kashdan, \& Hurling, 2011). These studies, however, measure individual strengths use and well-being in very general terms, applicable to a variety of settings and not explicitly in the workplace. Proactive behaviour is evident when employees take the initiative to improve their current work situation, or when they create better conditions for themselves, rather than passively adapting to circumstances (Crant, 2000).
Individual deficits are ways of behaving, feeling or thinking that do not necessarily come instinctively to an individual and that the person does not automatically enjoy doing, but in which the person can become competent if these deficits are developed in such a way that they are improved (Meyers, Van Woerkom, De Reuver, Bakker, \& Oberski, 2015). During performance management, supervisors or managers assess individuals' performance and provide feedback so that they can optimise their performance, which requires attention to deficit correction (Torrente, Salanova, Llorens \& Schaufeli, 2012). Research shows that when employees are proactive towards deficit correction, they tend to learn continuously (Rowold \& Schilling, 2006).

\section{Strengths use, thriving, performance and performance-related pay}

Individuals' performance at work reflects their level of functioning (Sarkar \& Fletcher, 2014). Two of the aspects of performance used by Bakker and Demerouti (2008), namely, task performance and contextual performance, are often investigated. Task performance is 'performance on required duties and responsibilities' (Sparrowe, Liden, Wayne, \& Kraimer, 2001, p. 320) as an integral part of one's job assignments. It contributes directly to the technical core of the organisation. Contextual performance can be defined as 'individual behaviour that is discretionary, not directly or explicitly recognised by the formal reward system, and in the aggregate promotes the efficient and effective functioning of the organisation' (Organ, 1988 , p. 4). It is interchangeable with organisational citizenship behaviour (Mackenzie, Podsakoff, \& Ahearne, 1998) and contributes less directly to the organisation (Motowidlo, Borman, \& Schmit, 1997). Instead, it promotes a social and psychological environment that contributes to the accomplishment of tasks (Borman \& Motowidlo, 1997; Goodman \& Svyantek, 1999). Positive organisational support influences some important employee attitudes and behaviours such as organisational citizenship behaviour, among other attitudinal variables (Wayne, Shore, Boomer, \& Tetrick, 2002). These employee attitudes and reactions, in turn, are said to influence employee performance (Wayne et al., 2002).

An employee's relationship with an organisation is based on the exchange of performance and positive work behaviour for positive outcomes at work. Because Van Woerkom et al. (2016) based the concepts of POS for strengths use and for deficit correction on the foundation of the organisational support theory, the researcher proposes that POS for strengths use and for deficit correction is a contributor to thriving in the workplace and performance. Employees who feel that their organisation cares about their well-being will reciprocate and care about the success of the organisation (Rhoades \& Eisenberger, 2002). Supportive organisations boost employees' feelings of being respected and appreciated, which in turn stimulate the employees to acquire knowledge and skills and to absorb them with feelings of vitality and learning in the workplace (Mushtaq, Abid, Sarwar, \& Ahmed, 2017). 
According to Littman-Ovadia et al. (2017), strengths use by employees leads to positive affect, which in turn leads to positive functioning and attitudes (e.g. Fredrickson 2001). Initial evidence supports the role of positive affect in mediating the positive effects of a strengths-based climate on well-being (Van Woerkom \& Meyers, 2015). Bakker and Van Woerkom (2018) argued that employees can act in accordance with their authentic selves when they use their strengths (Peterson \& Seligman, 2004), which results in lower stress and depression because of work (Kernis \& Goldman, 2006; Sheldon \& Elliot, 1999). Moreover, employees who use their strengths, experience mastery (Bandura, 1997), which leads to better performance.

The process of measuring and successively managing organisational and employee performance to improve organisational effectiveness is seen as critical to the development and survival of the organisation (Den Hartog, Boselie, \& Paauwe, 2004). Performance-related pay is an individual-based incentive offered by an assessment of individual employees' work effort in relation to their contribution to organisational goals (Pendleton, Whitfield, \& Bryson, 2009). Managers can support employee thriving by linking rewards to performance. Performance-related pay will provide employees with a feeling of being rewarded and that their employer values them and their contribution. This is more likely to increase employees' commitment to the organisation and encourage them to contribute more (McClean \& Collins, 2011). Unfortunately, performance management in an academic environment is a complex and sensitive issue (Rabovsky, 2014; Sousa, de Nijs, \& Hendriks, 2010) with several inputs, outputs and outcomes, which are often unclear. Nonetheless, Nawaz and Muazzam (2015) report that performance-related pay systems have improved job satisfaction and performance of academics.

\section{Aims and hypotheses}

This study implies that POS for strengths use and employees' proactive behaviour towards strengths use and deficit correction can influence thriving at work and that strengths use and deficit correction can have an impact on performance via thriving. Performance-related pay might interact with thriving in influencing employees' performance. The following hypotheses were formulated.

Perceived organisational support for strengths use (Hypothesis 1a) and POSDC (Hypothesis 1b) predict thriving at work. Strengths use behaviour (Hypothesis 2a) and DCB (Hypothesis $2 \mathrm{~b})$ predict thriving at work. Thriving predicts performance (Hypothesis 3). Thriving mediates the relationships between POSSU, POSDC, SUB and DCB on the one hand and performance on the other hand (Hypothesis 4). Performancerelated pay moderates the relation between thriving at work and performance (Hypothesis 5).

\section{Research design Research approach}

A descriptive, cross-sectional and quantitative approach was used to gather data through the utilisation of questionnaires.
A cross-sectional method allows the researcher to examine various groups of individuals at a single point in time (Salkind, 2009).

\section{Research method}

\section{Participants}

A total of 276 employees were recruited from the Vaal University of Technology ( $n=118)$, the Tshwane University of Technology $(n=109)$ and the Central University of Technology $(n=49)$. Participants' ages ranged from 20 years to 79 years. The mean age of participants was 43.83 (SD = 11.10). Almost half of the respondents $(n=128)$ held a master's degree, while most respondents $(81.6 \%)$ had served in an academic profession for more than 5 years. Most participants $(80.4 \%)$ were permanently employed. The biographical and employee-related characteristics of the participants are described in Table 1.

\section{Instruments}

The following instruments were used in the empirical study.

Perceived organisational support for strengths use, DCB, strengths used and perceived organisational support for deficit correction were measured with the Strengths Use and Deficit Correction Scale (SUDCO) (Van Woerkom et al., 2016). The SUDCO consists of 30 items scored on a seven-point scale ranging from 0 (almost never) to 6 (almost always) and comprised of four dimensions, namely, POSSU, DCB, SUB and POSDC. Perceived organisational support for strengths use is measured by eight items (e.g. 'This organisation gives me the opportunity to do what I am good at'). Deficit correction behaviour is measured by seven items (e.g. 'At work, I focus on developing the things I struggle with').

TABLE 1: Characteristics of the participants $(n=276)$.

\begin{tabular}{llcc}
\hline Item & Category & Frequency & $\mathbf{\%}$ \\
\hline Gender & Male & 123 & 44.6 \\
Age & Female & 153 & 55.4 \\
& 20-30 years & 38 & 13.7 \\
& 31-40 years & 73 & 26.4 \\
& $41-50$ years & 87 & 31.5 \\
& 51-60 years & 58 & 21.0 \\
Home language & Over 60 years & 20 & 7.2 \\
& Afrikaans & 109 & 39.5 \\
& English & 66 & 23.9 \\
Highest qualification & African language & 101 & 36.6 \\
& Diploma & 7 & 2.5 \\
& Postgraduate diploma & 7 & 2.5 \\
& Bachelor's degree & 20 & 7.2 \\
& Honours degree & 31 & 11.2 \\
& Master's degree & 128 & 46.4 \\
& Doctoral degree & 83 & 30.1 \\
\hline \multirow{3}{*}{ Tenure } & Less than 5 years & 51 & 18.4 \\
& 5-10 years & 70 & 25.3 \\
& 11-15 years & 46 & 16.6 \\
& 16-20 years & 42 & 15.1 \\
& 21-25 years & 31 & 11.2 \\
& More than 25 years & 36 & 13.1 \\
\hline
\end{tabular}

Note: Percentages were rounded off to the first decimal and are approximate values. 
Strengths use behaviour is measured by seven items (e.g. 'I capitalise on my strengths at work'), and POSDC is measured by eight items (e.g. 'In this organisation, I receive training to improve my weak points'). Van Woerkom et al. (2016) found acceptable Cronbach's alpha values for the scales: POSSU: $\alpha=0.95$; DCB: $\alpha=0.89$; SUB: $\alpha=0.90$; and POSDC: $\alpha=0.90$.

The Thriving at Work Scale (Porath et al., 2012) was used to measure the level of thriving. It is a 10-item scale measuring two dimensions: learning (e.g. 'I continue to learn more and more as time goes by') and vitality ('I feel alive and vital'). Each subscale consists of five items. A Likert scale ranging from 1 (not at all) to 5 (to a great extent) is used to rate the 10 items. The alpha coefficient of the total scale was found to be 0.93 .

A scale from Goodman and Svyantek (1999) was adapted to measure job performance for task performance. This scale has nine items, but only six items were used, scored on a Likert-type scale ranging from 1 (low) to 10 (high). Respondents had to rate their perceptions regarding their job performance. Encompassing a single dimension, sample items of the scale include the following: 'I fulfil all the requirements of my job' and 'I perform well in the overall job by carrying out tasks as expected'. Goodman and Svyantek (1999) reported an internal reliability of 0.90 for the scale.

Contextual performance was measured using the adapted Organisational Citizenship Behaviour Scale (OCBS, Rothmann \& Rothmann, 2010). The OCBS consists of six items scored on a Likert-type scale varying from 1 (low) to 10 (high). Three items measure assistance to co-workers in the organisation. The other three measure assistance to the organisation. An example item of assistance to co-workers is 'I give up time to help co-workers who have work or nonwork problems'. An example item of assistance to the organisation is 'I take action to protect the organisation from potential problems'. The Cronbach alpha coefficients for the two scales were found to be 0.78 (assistance to co-workers) and 0.80 (assistance to the organisation).

A section of the High-Performance HR Practices Questionnaire (Mostafa \& Gould-Williams, 2014) was used to measure employee perceptions of the high-performance HR practice of performance-related pay. The section consists of four items (e.g. 'I have the opportunity to earn individual bonuses for my performance'). All items are rated according to an agreement-disagreement Likert format varying from 1 (strongly disagree) to 7 (strongly agree).

\section{Data analysis}

Statistical analyses were performed using two statistical programs, namely, Mplus Version 8 (Muthén \& Muthén, 1998-2017) and the SPSS 24 program (IBM Corp, 2016). Mplus was used to conduct confirmatory factor analyses. The SPSS 24 program (IBM Corp, 2016) was used to compute descriptive statistics. Maximum likelihood estimation with robust standard errors in Mplus was used as an estimator. The following indices were used to assess model fit for measurement and structural models (West, Taylor, \& Wu, 2012): (1) absolute fit indices, including the chi-square statistic, standardised root mean residual (SRMR), and root mean square error of approximation (RMSEA) (RMSEA and SRMR values lower than 0.08 indicate a close fit between the model and the data); (2) incremental fit indices, including the Tucker-Lewis index (TLI) and comparative fit index (CFI). The recommended value for TLI and CFI is 0.90 or higher.

An estimate of scale reliability ( $\rho$ ) was obtained for each scale (Raykov, 2009). The statistical significance was set at $p<0.01$. The practical significance of correlations and percentages of variance explained, were assessed by using the guidelines of Cohen (1988). A correlation of 0.5 is large, 0.3 is moderate, and 0.1 is small. Cohen (1988) provides the following guidelines concerning the practical significance of $R^{2}$ : 0.25 - large effect; 0.09 - medium effect, 0.01 - small effect. The indirect effects of strength use on performance (via thriving) were computed using the procedure explained by Hayes (2018).

A moderation model with the effect of thriving on performance moderated by performance-related pay was estimated using PROCESS Version 3 (Hayes, 2018) in SPSS 24 (IBM Corp, 2016). The independent variable and the moderator were not centred, given that factor scores were used in the analysis.

\section{Research procedure}

Three universities of technology in Gauteng and the Free State were approached. An electronic questionnaire in English via the myresearchsurvey.com platform was circulated using email. The questionnaire took approximately 30-45 min to complete. A cover letter clarified the purpose of the study and emphasised the confidentiality and anonymity of the research project. Because participation in the project was voluntary, the participants had the option to withdraw at any time. Participants completed the online questionnaire from the middle of February to mid-September 2017. Responses to the items were illustrated in an Excel spreadsheet, after which the spreadsheet was converted to an SPSS dataset for analysis.

\section{Ethical consideration}

Three universities of technology in Gauteng and the Free State were approached. Their management gave permission and provided ethical clearance to conduct the study. Ethical clearance was also obtained from the ethics committee at the university from which the research was undertaken.

\section{Results \\ Testing the measurement model}

Based on the results of previous studies (Stander \& Mostert, 2013; Van Woerkom et al. 2016) regarding the factor structures of the measures included in this study, it was decided to test one measurement model. The model consisted of three latent 
variables: strengths use and deficit improvement, thriving and performance. Strengths use and deficit improvement consisted of four first-order latent variables: perceived organisational support for strengths use (measured by seven items), DCB (measured by seven items), individual SUB (measured by eight items) and perceived organisational support for deficit correction (measured by eight items). Thriving consisted of two first-order latent variables: vitality (measured by five items) and learning (measured by five items). Performance consisted of two first-order latent variables: task (measured by six items) and contextual (measured by seven items). All the latent variables in Model 1 were allowed to correlate.

The final measurement model showed acceptable fit to the data $\left(\chi^{2}=1889.21, d f=1105 ; p<0.001 ; \mathrm{CFI}=0.91\right.$; TLI $=0.91$; $\mathrm{RMSEA}=0.05, p=0.38[0.047,0.055] ; \mathrm{SRMR}=0.06)$. Items all loaded on their respective constructs as expected. The standardised regression coefficients were all statistically significant $(p<0.001)$.

\section{Descriptive statistics and product-moment correlations}

The descriptive statistics and reliability coefficients of the measuring instruments, as well as the product-moment correlation coefficients between the constructs, are reported in Table 2.

Frequency analyses showed that approximately $11 \%$ of the participants did not thrive at all. However, regarding the dimensions of thriving, 22\% lacked energy and did not look forward to each day. Furthermore, 10\% reported that they were not learning and improving. A total of $42 \%$ of the sample endorsed the 'agree' and 'strongly agree' responses on the vitality dimension, while $57 \%$ endorsed these responses on the learning dimension. Table 2 shows that the reliabilities of all the measuring instruments were acceptable, ranging from 0.81 to 0.96 (Nunnally \& Bernstein, 1994). Both dimensions of thriving (learning and vitality) were practically and statistically significantly related to the four dimensions of SUDCO (POSSU, SUB, DCB and POSDC), with medium effects. Furthermore, both dimensions of thriving (learning and vitality) were practically and statistically significantly related to task and contextual performance, with a small effect.

TABLE 2: Descriptive statistics, reliability coefficients and correlations of the scales $(n=276)$.

\begin{tabular}{lcccccccccc}
\hline Variable & $\boldsymbol{\rho}$ & Mean & SD & $\mathbf{1}$ & $\mathbf{2}$ & $\mathbf{3}$ & $\mathbf{4}$ & $\mathbf{5}$ & $\mathbf{6}$ & $\mathbf{7}$ \\
\hline 1. Vitality & 0.95 & 5.37 & 1.33 & - & - & - & - & - & - & - \\
2. Learning & 0.91 & 5.93 & 0.93 & 0.69 & - & - & - & - & - & - \\
3. POSSU & 0.96 & 4.06 & 1.23 & 0.43 & 0.48 & - & - & - & - & - \\
4. DCB & 0.84 & 4.50 & 0.73 & 0.44 & 0.48 & 0.35 & - & - & - & - \\
5. SUB & 0.91 & 4.85 & 0.75 & 0.44 & 0.35 & 0.44 & 0.43 & - & - & - \\
6. POSDC & 0.93 & 3.75 & 1.17 & 0.34 & 0.49 & 0.56 & 0.34 & 0.30 & - & - \\
7. Task performance & 0.87 & 3.07 & 1.70 & 0.19 & 0.21 & 0.13 & 0.13 & 0.14 & 0.11 & - \\
8. Contextual performance & 0.81 & 8.41 & 1.10 & 0.17 & 0.19 & 0.12 & 0.12 & 0.12 & 0.09 & 0.51 \\
\hline
\end{tabular}

\section{Testing the structural model}

The final measurement model showed acceptable fit to the data $\left(\chi^{2}=2164.56, d f=1303 ; p<0.001 ; \mathrm{CFI}=0.91\right.$; TLI $=0.91$; $\mathrm{RMSEA}=0.05, p=0.68$ [0.045, 0.053]; SRMR $=0.07)$. Items all loaded on their respective constructs as expected. The standardised regression coefficients were all statistically significant $(p<0.001)$.

Table 3 shows the standardised regression coefficients for when thriving and performance were considered as dependent variables.

Table 3 and Figure 1 show that thriving at work is best predicted by three variables, namely, POSSU $(\beta=0.30$, $p<0.01)$, DCB $(\beta=0.25, p<0.05)$ and SUB $(\beta=0.25, p<0.05)$. Hypotheses $1 \mathrm{a}, 2 \mathrm{a}$ and $2 \mathrm{~b}$ are accepted. Strengths use and deficit correction by the organisation and the individual predicted $48.5 \%$ of the variance in thriving. Thriving at work predicted performance $(\beta=0.32, p<0.01)$. Hypothesis 3 is accepted. Thriving predicted $10.1 \%$ of the variance in performance. The independent variables (strengths use and deficit correction) explained 48\% (large effect; Cohen, 1988) of the variance in thriving. Thriving explained $10 \%$ (medium effect; Cohen, 1988) of the variance in performance.

\section{Indirect effects}

The procedure suggested by Hayes (2018) was followed to investigate the indirect effects of strength use and deficit correction on thriving at work. Bootstrapping (with 10000 samples) was used to construct two-sided bias-corrected $95 \%$ confidence intervals to evaluate the indirect effects.

TABLE 3: Standardised regression coefficients.

\begin{tabular}{lcccc}
\hline Variable & Estimate & SE & Est/SE & $p$ \\
\hline Thriving ON & & & & \\
$\quad$ POSSU & 0.30 & 0.09 & 3.38 & $0.001^{* *}$ \\
DCB & 0.25 & 0.13 & 2.10 & $0.050^{*}$ \\
SUB & 0.25 & 0.12 & 2.18 & $0.030^{*}$ \\
POSDC & 0.09 & 0.08 & 1.21 & 0.227 \\
Performance ON & & & & \\
$\quad$ Thriving & 0.32 & 0.09 & 3.44 & $0.001^{* *}$ \\
\hline
\end{tabular}

$\mathrm{SE}$, standard error; Est/SE, estimate divided by standard error; $c$, obtained significance value POSSU, perceived organisational support for strengths use; DCB, deficit correction behaviour SUB, strengths use behaviour; POSDC, perceived organisational support for deficit correction $*, p<0.05 ; * *, p<0.01$.

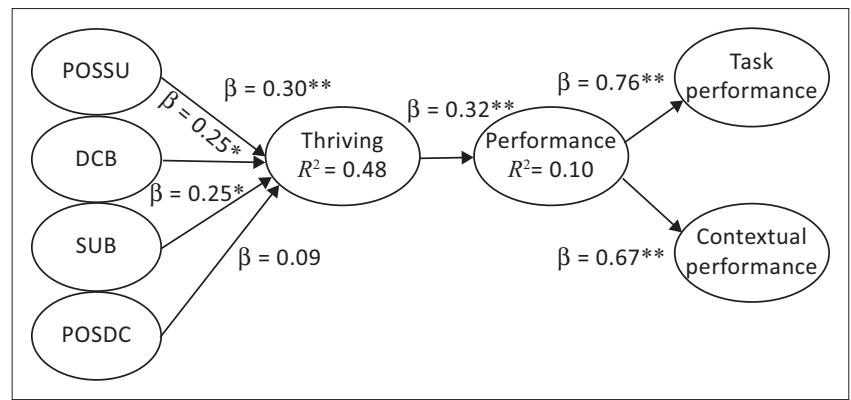

POSSU, perceived organisational support for strengths use; DCB, deficit correction behaviour; SUB, strengths use behaviour; POSDC, perceived organisational support for deficit correction. $*, p<0.05 ; * *, p<0.01$.

FIGURE 1: A structural model of thriving and performance. 
The results showed that POSSU $(p<0.02[0.03,0.19])$, DCB $(p=0.08[0.01,0.22])$ and SUB $(p=0.08[0.01,0.21])$ indirectly affected task and contextual performance via thriving. However, the indirect effect of POSDC on task and contextual performance via thriving included zero $(p=0.24[-0.01,0.11])$. Hypothesis 4 is partially accepted.

\section{Moderating effects}

Hierarchical regression analyses were performed to examine the extent to which performance-related pay moderates the influence of performance (task and contextual) on thriving of academics, following the procedure suggested by Hayes (2018). With thriving as the dependent variable, standardised scores of performance (predictor) were entered in the first step, followed by standardised performance-related pay scores (moderator) in the second step. To examine the possibility of a significant moderating effect, the interaction between thriving and performance-related pay was entered in the third and final step. According to Hayes (2018), evidence of a moderator effect is present when the interaction term between the predictor and moderator is significant. Regression results for the moderation effect are presented in Table 4.

Table 4 confirms that thriving had a positive effect on performance. However, performance-related pay had a small negative effect on performance. The interaction between thriving and performance-related pay accounted for a significant addition of $3 \%$ in the variance of performance $\left(F(1,272)=9.42, p<0.002, \Delta R^{2}=0.031\right)$. The complete regression model accounted for $11.45 \%$ of the variance in performance $(F(3,272)=11.72, p<0.001)$. The interaction of thriving and performance-related pay is significant $(\beta=0.08$, $\mathrm{SE}=0.03, t=2.85, p<0.01[0.02,0.13])$. In support of Hypothesis 5, performance-related pay was found to moderate the relationship between thriving and performance significantly. Overall, these results indicate that performancerelated pay has a direct influence on performance beyond what can be accounted for by thriving and moderates the relation between thriving and performance.

To examine the interaction effects that emerged, simple slopes were plotted of the performance-related pay-thriving linkage at the 16th, 50th and 84th percentiles, which corresponded to a standard deviation below the mean, the mean and a standard deviation above the mean (Hayes, 2018). Whether each slope was statistically significant was also tested.

As shown in Figure 2, the thriving-performance linkage did not exist in the low performance-related pay condition

TABLE 4: Regression results for the moderation effect.

\begin{tabular}{lcccccc}
\hline Variable & Estimate & $\mathrm{SE}$ & $\boldsymbol{t}$ & $\boldsymbol{p}$ & $\mathrm{LCI}$ & $\mathrm{UCI}$ \\
\hline Constant & -0.05 & 0.05 & -0.98 & 0.33 & -0.16 & 0.05 \\
Thriving & 0.35 & 0.06 & 5.72 & $0.00 *$ & 0.23 & 0.47 \\
Performance-related pay & -0.11 & 0.04 & -2.72 & $0.00 *$ & -0.19 & -0.03 \\
Interaction & 0.14 & 0.04 & 3.07 & $0.00 *$ & 0.05 & 0.22 \\
\hline
\end{tabular}

$\mathrm{SE}$, standard error; $p$, obtained significance value; $\mathrm{LCl}$, lower confidence interval; $\mathrm{UCl}$, upper confidence interval.

$*, p<0.01$.

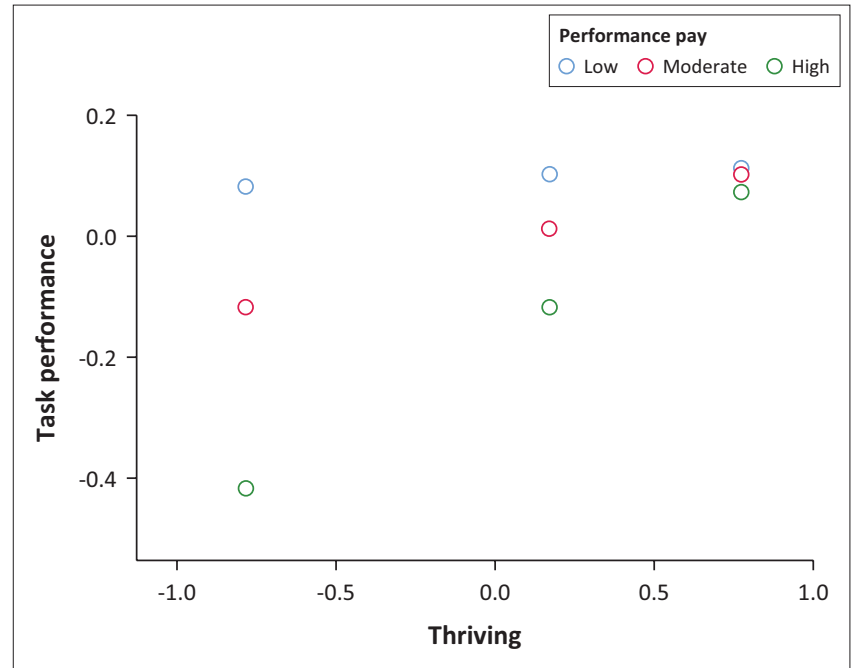

FIGURE 2: Interaction between thriving and performance-related pay.

(simple slope $=-1.52, p<0.059[-0.01,0.30])$, but this linkage was stronger in the moderate (simple slope $=-0.31, p<0.0001$ $[0.19,0.43])$ and high performance-related pay condition (simple slope $=1.49, p<0.0001[0.35,0.76])$. Specifically, when performance-related pay was perceived to be high, those individuals who thrived performed much better than those who did not thrive. However, when performance-related pay was perceived to be low, there were small differences between those who thrived and those who did not thrive. Thus, Hypothesis 5 is supported for task performance. No interaction effect was found for contextual performance.

\section{Discussion}

This study tested a structural model of POSSU and for deficit correction, individual strengths use and deficit correction, thriving at work and performance among South African academics. The study also aimed to investigate whether perceived performance-related pay would moderate the relation between thriving and performance. While the results showed that approximately $11 \%$ of employees did not thrive at all, a lack of energy was evident in $22 \%$ of the sample. Moreover, $58 \%$ of the sample did not show optimal vitality scores, while $43 \%$ did not function optimally concerning learning. The results revealed that POSSU, as well as individual strengths use and deficit correction, predicted thriving at work. Thriving predicted task and contextual performance.

An analysis of correlations showed that perceived support by the organisation for strengths use and deficit correction for academics were both positively associated with vitality and learning (which are dimensions of thriving at work). The structural model confirmed that POSSU had an impact on thriving of employees. Therefore, when these institutions supported the use of talents and strengths during the performance of tasks and academic duties, employees felt the most vitality. Deficit correction behaviour and strengths used by individual academics also contributed to thriving at work. When academics could develop their weak points and improve on their tasks and academic duties, they felt more 
energised and experienced learning. Together, these three variables (i.e. perceived organisational support for strengths use, individual strengths use and deficit correction) explained a large percentage of the variance in thriving at work.

The results showed that POS for strengths use was the strongest predictor of thriving at work. Perceived organisational support for strengths use refers to employees' beliefs and observations that their institutions encourage the use and application of their strengths in the workplace (Van Woerkom et al., 2016). While previous research has shown that POS for strengths use is a significant predictor of work engagement (Stander \& Mostert, 2013), this study confirmed its predictive value for thriving at work. Employees who perceive that their institutions supported their strengths use indeed reported that they experienced energy and learning at work (Spreitzer et al., 2005). Wiesenfeld et al. (2001) argued that support from organisations increases the workers' feelings of being respected and appreciated and might have enhanced their motivation for learning new things, as well as their energy.

However, individual strengths use and deficit correction also contributed to the thriving of individuals. Previous research confirms that when individuals know, develop and utilise their strengths, it leads to positive psychological and behavioural outcomes (Biswas-Diener et al., 2011). Individual deficits are ways of behaving, feeling or thinking that do not necessarily come instinctively to an individual and that the person does not automatically enjoy doing but in which the person can become competent if these deficits are developed in such a way that they are improved (Meyers et al., 2015).

Thriving at work predicted task and contextual performance of academics. Previous studies revealed that engaged employees had high task performance (Ho, Wong, \& Lee, 2011). The analyses showed that POS for strengths use, as well as strengths use and deficit correction by the individual, indirectly affected performance via thriving. Therefore, creating a climate for supporting strengths use in organisations affected academics' thriving and resulting from that, their task and contextual performance. The increase in thriving and performance could probably be attributed to the positive affect that individuals experience when they receive positive support for strengths use by their organisations. Furthermore, their proactive behaviour when they use their strengths and correct their deficits (LittmanOvadia et al., 2017), the authenticity that they experience when they use their strengths (Peterson \& Seligman, 2004) and their mastery experiences (Bandura, 1997) probably led to performance improvement.

The results showed that perceived performance-related pay practices interacted with thriving to impact task performance. In fact, performance-related pay had a small negative effect on performance. The moderation analyses showed that if the performance-related pay was perceived to be poor, nonthriving employees believed that they performed relatively well. However, when performance-related pay was seen to be good, thriving employees perceived that they performed well, while non-thriving employees perceived that they performed poorly. Therefore, it seems that perceived performance-related pay practices play a significant role in how thriving impacts employees' perceived performance: Firstly, poor performance-related pay practices may lead to non-thriving employees believing that they are performing well, while they do not perform well. Secondly, thriving employees seem to perform at their best when performancerelated pay practices are perceived to be good. The results of this study suggest that good performance-related pay practices might be vital to strengthen the linkage between thriving and performance.

\section{Conclusion}

\section{Limitations and suggestions for future research}

Various study limitations should be noted. Firstly, as this was a cross-sectional study, it comes with the limitation that statements made about causality do not stand their ground because of the study being solely a snapshot (Singleton \& Straits, 2010). Secondly, data on all variables in this study were based on self-reports, and this may lead to common method variance. Lastly, the relatively small sample size can be seen as a limitation. However, a cross-sectional study serves for this research, as the current data and evidence from the literature on which this study was based provide suitable ground to interpret the associations among the variables. Nonetheless, to be able to draw longitudinal conclusions, a suggestion for future research would be to include longitudinal and multilevel studies, in which the effects of this study's variables are measured over a more extended period instead of at one point in time (Pallant, 2010).

\section{Recommendations}

Higher education institutions must invest resources to enable academics to thrive at work via the balanced strength- and deficit-based approach. This approach should be seen as a core development tool for academics to increase employees' thriving at work. Thriving matters for better performance and academics seem to perceive performance-related pay as essential to thrive. Time should be devoted to developing a proper performance-related pay management structure and process by involving all role players to ensure a shared understanding of the purpose, implementation and what performance at different levels looks like (Seyama \& Smith, 2013). Practices such as job design, rewards and evaluations should be re-evaluated and reconstructed to fit in with the strengths-based culture or an optimal mix of strengths and deficits, leading employees to promote learning and vitality at work (Spreitzer et al., 2005).

Other than devoting time to the creation of a well-structured performance-related pay management system, supervisors, human resource practitioners and other key organisational members should support a strengths-based culture at higher education institutions by providing the necessary resources and integrating this culture into the policies and practices of the organisations (Van Woerkom \& Meyers, 2015). 
Strengths use and support for strengths use are associated with self-starting behaviour, and together they lead to higher levels of thriving at work.

\section{Acknowledgements Competing interests}

The authors declare that they have no financial or personal relationships that may have inappropriately influenced them in writing this article.

\section{Authors' contribution}

F.E.M. wrote the article. S.R. conducted the statistical analyses and assisted with interpreting the results and editing the article.

\section{References}

Abdullah, Z., Ahsan, N., \& Alam, S. S. (2009). The effect of human resource management practices on business performance among private companies in Malaysia. International Journal of Business and Management, 4(6), 65-72 https://doi.org/10.5539/ijbm.v4n6p65

Allen, D. G., Shore, L. M., \& Griffeth, R. W. (2003). The role of POS in the voluntary turnover process. Journal of Management, 29, 99-118. https://doi. turnover process. Journal of

Bakker, A. B., \& Demerouti, E. (2008). Towards a model of work engagement. Career Development International, 13(3), 209-223. https://doi.org/10.1108/13620430 810870476

Bakker, A. B., Schaufeli, W. B., Leiter, M. P., \& Taris, T. W. (2008). Work engagement: An emerging concept in occupational health psychology. Work \& Stress, 22, 187-200. https://doi.org/10.1080/02678370802393649

Bakker, A., \& Van Woerkom, M. (2018). Strengths use in organizations: A positive approach of occupational health. Canadian Psychology, 59(1), 38-46. https://doi. org/10.1037/cap0000120

Bandura, A. (1997). Self-efficacy. The exercise of control. New York: Freeman.

Bartlett, K. R. (2001). The relationship between training and organizational commitment: A study in the health care field. Human Resource Development Quarterly, 12(4), 335-352. https://doi.org/10.1002/hrdq.1001

Biswas-Diener, R., Kashdan, T. B., \& Minhas, G. (2011). A dynamic approach to psychological strength development and intervention. The Journal of Positive Psychology, 6, 106-118. https://doi.org/10.1080/17439760.2010.545429

Borman, W. C., \& Motowidlo, S. J. (1997). Task performance and contextual performance: The meaning for personnel selection research. Human Performance, 10(2), 99-109. https://doi.org/10.1207/s15327043hup1002_3

Botha, C., \& Mostert, K. (2014). Structural model of job resources, organisational and individual strengths use and work engagement. SA Journal of Industria Psychology/SA Tydskrif vir Bedryfsielkunde, 40(1), Art. \#1135, 11 pages. https:// doi.org/10.4102/sajip.v40i1.1135

Bouskila-Yam, O., \& Kluger, A. N. (2011). Strength-based performance appraisal and goal setting. Human Resource Management Review, 21, 137-147. https://doi. org/10.1016/j.hrmr.2010.09.001

Brown, D. J., Arnold, R., Fletcher, D., \& Standage, M. (2017). Human thriving: A conceptual debate and literature review. European Psychologist, 22(3), 167-179. https://doi.org/10.1027/1016-9040/a000294

Buckingham, M., \& Clifton, D. O. (2001). Now, discover your strengths: How to develop your talents and those of the people you manage. London: Simon \& Schuster.

Carmeli, A., \& Spreitzer, G. M. (2009). Trust, connectivity, and thriving: Implications for innovative behaviours at work. The Journal of Creative Behavior, 43, 169-191. $\mathrm{https} / / /$ doi.org/10.1002/j.2162-6057.2009.tb01313.x

Clifton, D. O., \& Harter, J. K. (2003). Strengths investment. In K. S. Cameron, J. E. Dutton, \& R. E. Quinn (Eds.), Positive organizational scholarship: Foundations of a new discipline (pp. 111-121). San Francisco, CA: Berrett-Koehler.

Cohen, J. (1988). Statistical power analysis for the behavioral sciences. Orlando, FL: Academic Press.

Crant, J. M. (2000). Proactive behavior in organizations. Journal of Management, 26(3), 435- 462. https://doi.org/10.1177/014920630002600304

Den Hartog, D. N., Boselie, P., \& Paauwe, J. (2004). Performance management: A model and research agenda. Rotterdam: Erasmus University.

Eisenberger, R. L., Fasolo, P., \& Davis-LaMastro, V. (1990). Perceived organizational support and employee diligence, commitment, and innovation. The Journal of Applied Psychology, 75, 51-59. https://doi.org/10.1037/0021-9010.75.1.51

Els, C., Mostert, K., \& Van Woerkom, M. (2018). Investigating the impact of a combined approach of perceived organisational support for strengths use and deficit correction on employee outcomes. SA Journal of Human Resource Management/ SA Tydskrif vir Menslikehulpbronbestuur, 16, a882. https://doi.org/10.4102/ sajhrm.v16i0.882
Fredrickson, B. L. (2001). The role of positive emotions in positive psychology: The broadenand-build theory of positive emotions. American Psychologist, 56, 218-226.

Goodman, S. A., \& Svyantek, D. J. (1999). Person-organization fit and contextual performance: Do shared values matter. Journal of Vocational Behavior, 55(2), 254-275. https://doi.org/10.1006/jvbe.1998.1682

Govindji, R., \& Linley, P. A. (2007). Strengths use, self-concordance and well-being Implications for strengths coaching and coaching psychologists. International Coaching Psychology Review, 2(2), 143-153.

Harzer, C., \& Ruch, W. (2013). The application of signature character strengths and positive experiences at work. Journal of Happiness Studies, 14, 965-983. https:// doi.org/10.1007/s10902-012-9364-0

Hayes, A. F. (2018). Introduction to mediation, moderation, and conditional process analysis: A regression-based approach (2nd edn.). New York: Guilford Press.

Ho, V. T., Wong, S.-S., \& Lee, C. H. (2011). A tale of passion: Linking job passion and cognitive engagement to employee work performance. Journal of Management Studies, 48, 26-47. https://doi.org/10.1111/j.1467-6486.2009.00878.x

IBM Corp. (2016). IBM SPSS statistics: Version 23. Chicago, IL: IBM Corporation.

Keenan, E. M., \& Mostert, K. (2013). Perceived organisational support for strengths use: The factorial validity and reliability of a new scale in the banking industry South African Journal of Industrial Psychology, 39, 1-12. https://doi.org/10.4102/ sajip.v39i1.1052

Kernis, M. H., \& Goldman, B. M. (2006). A multicomponent conceptualization of authenticity: Theory and research. Advances in Experimental Social Psychology, 38, 283-357. https://doi.org/10.1016/S0065-2601(06)38006-9

Lavy, S., \& Littman-Ovadia, H. (2016). My better self: Using strengths at work and work productivity, organizational citizenship behavior and satisfaction. Journal of
Career Development, 44(2), 95-109. https://doi.org/10.1177/0894845316634056

Linley, P. A., \& Harrington, S. (2006a). Strengths coaching: A potential-guided approach to coaching psychology. International Coaching Psychology Review, 1(1), 37-46.

Linley, P. A., \& Harrington, S. (2006b). Playing to your strengths. The Psychologist, 19(2), 86-89.

Linley, P. A., Joseph, S., Harrington, S., \& Wood, A. M. (2006). Positive psychology: Past, present, and (possible) future. Journal of Positive Psychology, 1, 3-16. https://doi. org/10.1080/17439760500372796

Littman-Ovadia, H., \& Lavy, S. (2016). Going the extra mile: Perseverance as a key character strength at work. Journal of Career Assessment, 24(2), 240-252. https:// character strength at work. Journal of
doi.org/10.1177/1069072715580322

Littman-Ovadia, H., Lavy, S., \& Boiman-Meshita, M. (2017). When theory and research collide: Examining correlates of signature strengths use at work. Journal of coppiness Studies, 18, 527-548. https://doi.org/10.1007/s10902-016-9739-8

Littman-Ovadia, H., \& Steger, M. (2010). Character strengths and well-being among volunteers and employees: Toward an integrative model. The Journal of Positive Psychology, 5(6), 419-430. https://doi.org/10.1080/17439760.2010.516765

Longenecker, C. O. (2010). Coaching for better results: Key practices of high performance leaders. Industrial and Commercial Training, 43(1), 32-40. https:// doi.org/10.1108/00197851011013698

MacKenzie, S. B., Podsakoff, P. M., \& Ahearne, M. (1998). Some possible antecedents and consequences of in-role and extra-role salesperson performance. The Journal of Marketing, 62(3), 87-98. https://doi.org/10.2307/1251745

McClean, E., \& Collins, C. J. (2011). High-commitment HR practices, employee effort, and firm performance: Investigating the effects of HR practices across employee
groups within professional services firms. Human Resource Management, 50, groups within professional services firms. Huma
341-363. https://doi.org/10.1002/hrm.20429

Meyers, M. C., Van Woerkom, M., De Reuver, R. S. M., Bakk, Z., \& Oberski, D. L. (2015). Enhancing psychological capital and personal growth initiative: Working on Enhancing psychological capital and personal growth initiative: Working on strengths or deficiencies. Journal
doi.org/10.1037/cou0000050

Mostafa, A. M. S., \& Gould-Williams, J. S. (2014). Testing the mediation effect of person-organization fit on the relationship between high-performance HR practices and employee outcomes in the Egyptian public sector International Journal of Human Resource Management, 25, 276-292. https://doi.org/10.1080/ 09585192.2013.826917

Mostert, K., Theron, B., \& De Beer, L. T. (2017). Validating strengths use and deficit correction behaviour scales for South African first-year students. SA Journal of Industrial Psychology/SA Tydskrif vir Bedryfsielkunde, 43, a1395. https://doi. org/10.4102/sajip.v43.1395

Motowidlo, S. J., Borman, W. C., \& Schmit, M. J. (1997). A theory of individual differences in task and contextual performance. Human Performance, 10(2), 71-83. https://doi.org/10.1207/s15327043hup1002 1

Mphahlele, P., Els, C., De Beer, L. T., \& Mostert, K. (2018). Investigating strengths and deficits to increase work engagement: A longitudinal study in the mining industry. $S A$ Journal of Human Resource Management/SA Tydskrif vir Menslikehulpbronbestuur, 16, a900. https://doi.org/10.4102/sajhrm.v16i0.900

Mushtaq, M., Abid, G., Sarwar, K., \& Ahmed, S. (2017). Forging ahead: How to thrive at the modern workplace. Iranian Journal of Management Studies, 10(4), 783-818.

Muthén, L. K., \& Muthén, B. O. (2012). Mplus users' guide (6th edn.). Los Angeles, CA: Muthén \& Muthén.

Nawaz, B., \& Muazzam, A. (2015). Performance related pay of university employees: A comparison of public and private sector universities of Pakistan. Pakistan Business Review, 17(1), 183-200.

Nunnally, J. C., \& Bernstein, I. H. (1994). Psychometric theory (3rd edn.). New York: McGraw-Hill.

Organ, D. W. (1988). Organizational citizenship behavior: The good soldier syndrome. Lexington, United Kingdom: Lexington Books/DC Heath and Com. 
Page, K. M., \& Vella-Brodrick, D. A. (2008). The 'what', 'why' and 'how' of employee well-being: A new model. (Unpublished master's dissertation.) Monash University, well-being: A new mod
Caulfield, Australia.

Pallant, J. (2010). SPSS survival manual (4th edn.). London, United Kingdom: McGrawHill Education.

Paterson, T. A., Luthans, F., \& Jeung, W. (2014). Thriving at work: Impact of psychological capital. Journal of Organizational Behavior, 35, 434-446. https:// doi.org/10.1002/job.1907

Pendleton, A., Whitfield, K., \& Bryson, A. (2009). The changing use of contingent pay at the modern British workplace. In W. Brown, A. Bryson, J. Forth \& K. Whitfield (Eds.), The evolution of the modern workplace (pp. 256-284). Cambridge: Cambridge University Press.

Peterson, C., \& Seligman, M. E. P. (2004). Character strengths and virtues: A handbook and classification. New York: Oxford University Press.

Porath, C. L., Spreitzer, G., Gibson, C., \& Garnett, F. G. (2012). Thriving at work: Toward its measurement, construct validation, and theoretical refinement. Journal of Organizational Behavior, 33, 250-275. https://doi.org/10.1002/job.756

Rabovsky, T. M. (2014), Using data to manage for performance at public universities. Public Administration Review, 74(2), 260-272. https://doi.org/10.1111/puar.12185

Raykov, T. (2009). Interval estimation of revision effect on scale reliability via covariance structure analysis. Structural Equation Modeling, 16, 539-555. https:// doi.org/10.1080/10705510903008337

Rhoades, L., \& Eisenberger, R. (2002). Perceived organizational support: A review of the literature. The Journal of Applied Psychology, 87, 698-714. https://doi. org/10.1037/0021-9010.87.4.698

Roberts, L. M., Spreitzer, G., Dutton, J., Quinn, R., Heaphy, E., \& Barker, B. (2005). How to play to your strengths. Harvard Business Review, 83(1), 75-80.

Rothmann, S., \& Rothmann, S. (Jr). (2010). Factors associated with employee engagement in South African organisations. SA Journal of Industrial Psychology/ SA Tydskrif vir Bedryfsielkunde, 36(1), 1-12.

Rowold, J., \& Schilling, J. (2006). Career-related continuous learning: Longitudinal predictive power of employees' job and career attitudes. Career Development International, 11(6), 489-503. https://doi.org/10.1108/13620430610692917

Ryan, R. M., \& Deci, E. L. (2017). Self-determination theory: Basic psychological needs in motivation, development, and wellness. New York: Guilford Press.

Salkind, N. J. (2009). Exploring research (7th edn.). Upper Saddle River, NJ: Pearson Prentice Hall.

Sarkar, M., \& Fletcher, D. (2014). Ordinary magic, extraordinary performance: Psychological resilience and thriving in high achievers. Sport, Exercise, and Performance Psychology, 3, 46-60. https://doi.org/10.1037/spy0000003

Seligman, M. E. P. (2011). Flourish: A visionary new understanding of happiness and well-being. New York: Free Press.

Seligman, M., \& Csikszentmihalyi, M. (2000). Positive psychology: An introduction. American Psychologist, 55, 5-14. https://doi.org/10.1037/0003-066X.55.1.5

Seyama, S., \& Smith, C. (2013). An exploration of the University of Johannesburg heads of departments' experiences and perceptions of the university's performance management system. In F. E. Gouws \& C. C. Wolhuter (Eds.), Educational research in South Africa: Practices and perspectives (SAERA 2013 Conference Proceedings) (pp. 223-249). Cape Town: Oxford University Press.

Sheldon, K. M., \& Elliot, A. J. (1999). Goal striving, need satisfaction, and longitudinal well-being: The self-concordance model. Journal of Personality and Social Psychology, 76, 482-497. https://doi.org/10.1037/0022-3514.76.3.482

Sienstra, M. (2010). Strength-based development as organisation approach: Will it lead to enhanced task performance and organizational citizenship behaviour, and is this relation mediated by subjected well-being? (Unpublished master's dissertation.) Tilburg University, Tilburg The Netherlands.
Singleton, R. A., \& Straits, B. C. (2010). Approaches to social research. New York: Oxford University Press.

Sousa, C. A. A., de Nijs, W. F., \& Hendriks, P. H. J. (2010). Secrets of the beehive: Performance management in university research organizations. Human Relations, 63(9), 1439-1460. https://doi.org/10.1177/0018726709357083

Sparrowe, R. T., Liden, R. C., Wayne, S. J., \& Kraimer, M. L. (2001). Social networks and the performance of individuals and groups. Academy of Management Journal, 44(2), 316-325.

Spreitzer, G. M., Lam, C. F., \& Fritz, C. (2010). Engagement and human thriving Complementary perspectives on energy and connections to work. In A. B. Bakker \& M. Leiter (Eds.), Work engagement: A handbook of essential theory and research (pp. 132-146). New York: Psychology Press.

Spreitzer, G. M., \& Porath, C. (2012). Creating sustainable performance. Harvard Business Review, 90, 92-99.

Spreitzer, G. M., \& Sutcliffe, K. (2007). Thriving in organizations. In D. Nelson \& C. Cooper (Eds.), Positive organizational behavior: Accentuating the positive at work
(pp. 74-85). London, United Kingdom: Sage. https://doi.org/10.4135/978144 6212752.n6

Spreitzer, G. M., Sutcliffe, K., Dutton, J., Sonenshein, S., \& Grant, A. M. (2005). A socially embedded model of thriving at work. Organization Science, 16, 537549. https://doi.org/10.1287/orsc.1050.0153

Stander, F. W., \& Mostert, M. (2013). Assessing the organisational and individual strengths use and deficit improvement amongst sport coaches. SA Journal of Industrial Psychology, 39(2), 1-13. https://doi.org/10.4102/ sajip.v39i2.1160

Torrente, P., Salanova, M., Llorens, S., \& Schaufeli, W. B. (2012). Teams make it work: How team work engagement mediates between social resources and performance in teams. Psicothema, 24(1), 106-112.

Van Woerkom, M., \& Meyers, M. C. (2015). My strengths count! Human Resource Management, 54(1), 81-103. https://doi.org/10.1002/hrm.21623

Van Woerkom, M., Mostert, K., Els, C., Bakker, A. B., De Beer, L. T., \& Rothmann, S., Jr. (2016). Strengths use and deficit correction in organizations: The development and validation of a questionnaire. European Journal of Work and Organizational Psychology, 25(6), 960-975. https://doi.org/10.1080/135943 2X.2016.1193010

Wayne, S. J., Shore, L., Bommer, W., \& Tetrick, L. (2002). The role of fair treatment and rewards in perceptions of organizational support and leader-member exchange. Journal of Applied Psychology, 87, 590-598. https://doi.org/10.1037/0021 9010.87.3.590

Wood, A. M., Linley, P. A., Maltby, J., Kashdan, T. B., \& Hurling, R. (2011). Using personal and psychological strengths leads to increases in well-being over time: $A$
longitudinal study and the development of the strengths use questionnaire. Personality and Individual Differences, 50, 15-19. https://doi.org/10.1016/j. Personality and

West, S. G., Taylor, A. B., \& Wu, W. (2012). Model fit and model selection in structural equation modeling. In R. H. Hoyle (Ed.), Handbook of structural equation modeling (pp. 209-231). New York: The Guilford Press.

Wiesenfeld, B. M., Raghuram, S., \& Garud, R. (2001). Organizational identification among virtual workers: The role of need for affiliation and perceived work-based social support. Journal of Management, 27(2), 213-229. https://doi. org/10.1177/014920630102700205

Yuan, F. B. S., \& Woodman, R. W. (2010) Innovative behavior in the workplace: The role of performance and image outcome expectations. Academy of Management Journal, 53(2), 323-342. https://doi.org/10.5465/amj.2010.49388995

Zagenczyk, T., Scott, K. D., Gibney, R., Murrell, A. J., \& Thatcher, J. B. (2010). Socia influence and perceived organizational support: A social networks analysis. Organizational Behavior and Human Decision Processes, 111(2), 127-138. https:// doi.org/10.1016/j.obhdp.2009.11.004 